MICHAELA MORAVČÍKOVÁ*

\title{
STATE-CHURCH RELATIONS AND SECULAR PRINCIPLES IN THE SLOVAK REPUBLIC ${ }^{1}$
}

\section{HISTORICAL OUTLINE}

In the course of time, the territory of the present Slovak Republic has become part of several state bodies. Religion has always played an important role on the territory of the contemporary Slovak Republic. Repeatedly, this territory has found itself on the East-West lines of force. Let's mention the early Christian period, the Byzantine mission of Thessaloniki brothers Cyrilus and Methodius, and the latter prevalence of the Western rite. After the fall of Great Moravia in 906 the whole Slav metropolis gradually disappeared. It took from two to three centuries till the territory with Slav inhabitants integrated into the newly formed Hungaria, which was preserved for almost one thousand years. The part of the territory, where in the $9^{\text {th }}$ century the Pribina principality was situated, remained the historical core of the Slovak country. Teofilaktos (933-956), the Byzantine patriarch, sent Bulgarian monks to Hungaria to maintain the liturgy language as well as the whole Eastern Rite. The first bishop of Hungaria - Hieroteos, was one of those who came as a response.

* Dr, Institute for Legal Aspects of Religious Freedom, Faculty of Law, Trnava University in Trnava, Hornopotočná 23, 91843 Trnava, Slovakia, e-mail: moravcikova@gmail.com

${ }^{1}$ This work was supported by Slovak Research and Development Agency under the contract No. APVV-0024-12. 
The territory of present-day Slovakia, as integrated into the Hungarian kingdom, gradually fell into the sphere of the prevailing influence of the Western Church. In the $10^{\text {th }}$ to $12^{\text {th }}$ century the territory of presentday Slovakia was covered with a net of Benedictine, Cistercian and Premonstratesian monasteries that were centers of cultural and economic development. From the $9^{\text {th }}$ century on, two Christian rites have been organically present here - the Latin and the Byzantine one ${ }^{2}$. In the $20^{\text {th }}$ century, after the $2^{\text {nd }}$ World War, due to the Yalta treaties, it became a part of the so-called Eastern Block under the power dominance of the Soviet Union. During the Communist era, the development of statechurch relations was fatally disrupted.

During the post-war period churches represented an influential political power. According to a population census, $99,72 \%$ of inhabitants identified with a church and only $0,28 \%$ claimed to have no religion. Catholic Churches of Latin and Byzantine rite were the biggest and most influential, comprising $82,75 \%^{3}$ of inhabitants. Other significant churches were the Evangelical Church of Augsburg Confession and Calvinistic believers. Baptists, Adventists, Methodists, Orthodox and other churches had only minimum numbers of followers. Within the People's Democratic Regime, the government proclaimed the freedom of religion. All churches showed loyalty towards the restored Czechoslovak Republic. In Slovakia, the situation of the Catholic Church was a bit more complicated and its relations with the state more tense when compared with other churches. It paid a bitter price for its ties with the Hlinka's Public Party - the creator and bearer of force and control in the Slovak Republic in the years 1939-1945. The ban of Hlinka's Public Party and lawsuit with Tiso and other state representatives harmed also the Catholic Church, since the dividing line between Catholic Church and political Catholicism was not firmly laid. The government had a negative attitude towards a majority of Catholic

${ }^{2}$ Comp. P. Mosný, M. Laclavíková, History of state and law on the territory of Slovakia, I. From ancient times till 1848, Plzeň 2009, p. 93.

${ }^{3}$ Out of which 76,20\% were Roman Catholic and 6,55\% Greek Catholic. Comp. J. Pešek, M. Barnovský, Pod kuratelou moci. Cirkvi na Slovensku v rokoch 1953-1970, Bratislava 1999, p. 13. 
bishops who were connected with Tiso's former regime. Chief representatives of the Evangelical Church of Augsburg Confession had close political contacts with post-war, predominantly Evangelical leadership of the Democratic Party. The Reformed Church was practically lame and divided after the war in connection with the then troubled SlovakHungarian relations. Slovak clergy stood at the head of church, whose majority was comprised of believers of Hungarian nationality. The majority of clergy of Hungarian nationality did not have Slovak state citizenship and could not perform official functions within the church. Thus their impact on social development was minimal.

By the February subversion in 1948 and shortly after, dismantling of what was left of democracy in Czechoslovakia came to its peak. Communists took power. The primary interest of the communist regime was to manipulate churches according to its own interests via their representatives. Though, when these steps did not prove effective, communist force put the focus of anti-church activities on minimizing its social influence and establishing strict state control.

The Act No. 217/1949 Zb. ${ }^{4}$ created the State Office for Church Affairs as a central organ of state administration. One year later a law on economic provision of churches and religious associations by state was passed. This regulation enabled the state a differentiated approach towards the clergy. This law also brought to existence the requirement of "state approval" for clergy. Churches and religious associations ceased to have the character of public law subjects and became completely dependent on the state economically. A majority of church property, and church schools were nationalized. The State had control over liturgical, pastoral, social, charity, educational, economic and any other activity of churches. It established compulsory registration of churches; the clergy was enabled to engage in public performances only if approved by state. This approval was conditioned by their vow of loyalty to the republic.

The Communist state had never considered separation of church from state. It assumed that such a step within given historical conditions would raise the social influence of churches. It would also strength-

${ }^{4}$ „Zb.“, or since 1993 „Z.Z.“ - abbreviations for „Zbierka zákonov“, i.e. Collection of Acts. 
en the discipline of clergy towards church hierarchy. This represented a counter-productive element for the then state power struggling to disintegrate churches from within. Naturally, the strict totalitarian control of churches activated illegal activities of individual believers, clergy or various groups that were out of the reach of state control. They became the target of persecution by national security forces.

The period of 1948-1953 represented an extremely acute conflict situation in state-church relations. Churches resisted interference into their internal matters and restriction of religious freedom with occurred with a remarkable intensity. During the following stage, state power concentrated on "overcoming religious relics" through governmental interventions as well as party and state structures supporting the secularization and atheisation of society. Some bishops, priests and monks were imprisoned. Vacant positions of church leaders were occupied by administrators appointed by the communist government. The government also tried to control the activity of bishops.

In August 1948 communists came with an idea to create a national Catholic Church. Because of the ceremonial and disciplinary differences between Roman Catholics and Greek Catholics they consequently started to sort out the "Greek Catholic issue". They proposed the "return" of Greek Catholics to Orthodox Church. In 1946, a so-called "sobor" (council) took place in Lvov, western Ukraine. Here, the union with Rome was abolished and a return of Greek Catholics to the belief of their ancestors, to the Orthodox Church was proclaimed. Since the standpoints and acts of Russian communists were authoritative for Slovak communists, a similar procedure was chosen in Slovakia as well. After the Russian Orthodox Church delegations visit to Czechoslovakia (whose aim was to prepare fusion of Greek Catholic and Orthodox church in Slovakia), this political plan was given the name of Action P. On April 28, 1950, a sobor (council) of Greek Catholics with participation of Greek Catholic delegates appointed by state power took place in Prešov. It made a decision on the abolition of the Uzhorod Union from 1646, separation from Rome and return to the "father" Orthodox Church. At the same time it addressed the Orthodox Patriarch of Moscow and whole Russia to accept it under his church jurisdiction. On May 27, the Exarch of The Orthodox Church in Czechoslovakia 
- Jelefterij, received a letter from the State Office for Church Affairs. The letter acknowledged the legitimacy of decisions taken by Prešov sobor. From the point of view of state power the Greek Catholic church ceased to exist in Slovakia. Greek Catholic clergy, who refused to enter the Orthodox Church had to give up their profession as a cleric. In most cases they were interned and later on transferred to the Czech-German border region to work in agriculture or blue-collar jobs. Two Greek Catholic bishops were convicted of seditious activities and sentenced to prison for a long period.

Along with the Greek Catholic Church liquidation, monasteries and holy orders were closed down as well. This came as a response to their significance within the Catholic Church and influence on society.

At the break of March and April 1950, in an artificially constructed lawsuit against monastery and holy order representatives, monasteries were "revealed" as centers of sedition, where espionage was being organized, weapons collected and provocations are being prepared. Action $K$ took place on the night from April 12 to 13, 1950. Security forces seized the majority of monasteries and the monks were concentrated into detention camps. Even though massive security forces were put to operation, several sharp crashes appeared. Similar intervention against women's holy orders followed as a part of Action R. Interned nuns and monks were first re-educated, afterwards transferred to work in factory production, nuns especially to the Czech-German border region to work in the agriculture or textile industries.

After 1950, theological studies were available only at the Constantine-Methodius Theological Faculty in Bratislava and at the Orthodox Theological Faculty in Prešov. All the other theological institutes were closed down. The State took strict actions against "reactionary" priests, who were often imprisoned without a lawsuit or sentenced to military service to carry out hard labour in subsidiary technical battalions of the armed forces.

At the beginning of the fifties, hundreds of clergy were imprisoned or interned. Bishops were isolated and interned in the bishops' ministries or imprisoned. As for the Catholic Church a parallel church structure began to flourish in unofficially. It assumed some functions of the official Church. The state, on the other hand, organized the "Catholic 
clergy peace movement", in which it strived for establishing connections among priests who were willing to cooperate with state power. In doing so, the state could divide the Catholic Church in Czechoslovakia. However, the membership was very low and the movement did not have significant influence on society. Evangelical churches, in this period, did not come with a strong resistance against the state; the Calvinist Church found importance in the national problem and not the problem of loyalty towards the regime. Church press was subject to state control to such extent that in fact it did not any longer have religious character ${ }^{5}$.

Before 1968, the first symptoms of change in the churches political situation appeared. It was mainly under the influence of the MarxistChristian dialogue that was popular especially with French and Italian communists. This dialogue with Christians was found as one of the specific instruments of the ideological battle for suppression of the religious way of thinking with believers. Occasionally, requests to recompense the wrongdoing to believers and churches appeared. The Prague Spring in 1968, when Alexander Dubček became the first secretary of the Communist Party, began a limited democratization processes along with a new state church policy. The censorship of church press was eased, "cadre ceiling" for the religious was cancelled and communication between Catholic ordinaries and the Holy See was allowed. The government passed a decree that approved the activities of the Greek Catholic Church. Limits for accepting candidates for priesthood to theological faculties were cancelled. The Supreme Court was asked to go through the processes with Catholic hierarchy, representatives of monasteries and the like. Many officials and members of Communist Party reproached Party leadership for such an attitude. Party bodies planned changes of a larger extent within church policy than after the change of legal norms from 1949. These processes were much more striking in the Czech Republic than in Slovakia. Dialogue between the Marxists and Christians in Slovakia did not take place at all.

Occupation of Czechoslovakia by the armies of the five Warsaw Pact states in 1969 put the brake on state democratization processes.

\footnotetext{
${ }^{5}$ Comp. J. Pešek, M. Barnovský, Pod kuratelou moci, p. 20-21.
} 
A process of the so-called normalization was started. Representatives of hard line interests replaced pro-reform Party and state officials. They felt the situation had become the exclusion of churches from state control. A regression in the church-political situation and a return to statechurch relations from before 1968 followed. A new, state-collaboration movement of Catholic clergy - Pacem in terris ${ }^{6}$, was formed. Through this, the Communist Party wanted to penetrate the inside the Church and influence its activities according to Party's interests. State-church relations were reduced to church-political control and suppression of any church activities and public religious manifests. The time-consuming negotiations between Czechoslovakia and the Holy See were an exception. They negotiated about filling the vacant bishop seats, about theological faculties and reorganization of diocese boundaries so they did not overreach state boundaries. Pope Paul VI used the Praescriptorum Sacrosancti constitution from December 30, 1977 to create Slovak church province with a seat in Trnava ${ }^{7}$. The pressure of the Holy See as well as international-political pressure to realize the Helsinki commitments in Czechoslovakia got consequently stronger after K. Wojtyla's accession to the papacy. Church activity was increased; believers showed their discontent with the actions of state power towards churches and religion and demanded real religious freedom. Religious pilgrimages were became the events of revolt; the number of lay religious activists grew. On March 25, 1988, a manifestation that entered history as "the candle manifestation" took place in Bratislava. Some thousands of people from the whole republic found courage to gather at Hviezdoslav Square. Carrying candles in their hands they demonstrated their support of requests to defend religious and human rights. After the crowd did not respond to the call to disperse, a strong intervention of security

\footnotetext{
${ }^{6}$ John Paul II issued the Quidam episcopi bulla (Manifest of Holy Congregation for the Clergy about some associations and movements prohibited to clergy) in the beginning of March 1982. According to the bulla, those associations and movements are alien to priest service, which directly or indirectly, openly or secretly pursue political goals, even though they sometimes present them in a way as if they tried to support humanistic ideals, peace and social progress.

${ }^{7}$ The Qui divino constitution from the same day promoted the Trnava diocese to archdiocese.
} 
forces followed. It was one of the last acts of power before its eventual downfall. In spite of the fact that it was largely outside events which influenced the downfall of the regime, we cannot forget to mention the activities of churches and Catholic dissent. They constituted one of the strongest bodies representing resistance to the Communist regime in Slovakia.

It is necessary to realize that this evolution completely differs from the democratic development which took part in countries westward of the Berlin Wall at this time. Minor or major differences did exist between the Eastern Bloc countries as well. However, based on the above-mentioned we can state that conditions of religious life in Slovakia were extremely unfavourable. We can also generalize that the attitude of public authorities towards religious organizations was extremely hostile, and striving for the erasure of religion. MarxismLeninism was a state ideology ${ }^{8}$. This ideology was a background and a starting point of all government program documents. The Communist Party and its decisions were superior to all state bodies, and, in fact, they ruled the state. Marxist atheism was an integral part of state doctrine. In practice, it was often called "scientific atheism" and declared for a "most consequent" and integral system of materialist views refuting religious insight. It defined itself as a "superior form

${ }^{8}$ During the existence of the Czechoslovak Socialist Republic in the years 1948-1989, two constitutions were in force. The first one was the Constitution of the Czechoslovak Socialistic Republic from 9 May 1948, and the second one the 1960 Constitution of Czechoslovak Socialistic Republic. The first one concentrated all the features and contradictions of the period of its origin. First of all, it was due to the press of the Communist Party of Czechoslovakia for Marx-Leninist orientation, thus formally following in the 1920 Constitution of the Czechoslovak Republic in several matters. Particular institutes of the Constitution were, however, assigned class contents. Several postulates of democracy expressed in the Constitution were, however, often violated or not respected in a particular social and political practice. The freedom of conscience and belief was proclaimed in Articles 15-17, and the freedom of assembly and association in Art. 24. Churches and religious societies have not been mentioned in the Constitution explicitly.

In the Constitution approved on 11 July 1960, the postulates of Marx-Leninism on state and law were already manifested in all its provisions in full measure. It declaimed the victory of Socialism and the fulfilment of People's Democracy. It stipulated the principle of the leading role of the Communist Party of Czechoslovakia. Thus the law order protected also de iure the state power from the citizens and not vice versa. 
of atheism". Marxism-Leninism was present in the life of the whole society, in science, art, and social policy. Within the scope of civics, primary and secondary schoolers were obliged to become acquainted with its basics. At universities, Marx-Leninism and the International Working Movement History were compulsory subjects. These subjects were part of theology faculty curriculums as well. This Communist era "heritage" has to be considered when appreciating the current state of state-church relations, and the contemporary interference between the public authorities and religions "philosophies of life".

\section{RELIGIOUS DEMOGRAPHY, LEGAL AND ADMINISTRATIVE FRAMEWORK}

The contemporary Slovak Republic is a young independent state that came into existence on January 1, 1993 after the peaceful division of the Czech and Slovak Federative Republic.

The total number of inhabitants is 5397 036. In the most recent census taken in $2011^{10}, 75,6 \%$ of the resident population professed allegiance to a state-recognised church or religious society: $62 \%$ of the population declared their affiliation to the largest, the Roman Catholic Church, 3,8\% to the Byzantine Catholic Church, 5,9\% to the Lutheran Church of the Augsburg Confession, 1,8\% to the Reformed Christian Church and $0,9 \%$ to the Orthodox Church.

Numerical representation in other small churches could be expressed in hundredths of percents. $13,4 \%$ of the population declared themselves as being "without confession", 10,6\% of respondents did not answer the question about religious affiliation at all. In the census $0,5 \%$ of respondents (23 340) claimed membership in churches or religious societies that are not recognized by the state ${ }^{11}$.

${ }^{9}$ Slovník vedeckého ateizmu, ed. F. Vašečka, Bratislava 1983, p. 47.

${ }^{10}$ It took place according the Act 263/2008 Zb. on Census of Population, Houses and Apartments in 2011.

${ }^{11}$ Cf. Počet obyvatel'ov SR [online]. Štatistický úrad Slovenskej republiky, 2012, http://portal.statistics.sk/files/prezentacia-vybranych-vysledkov-sodb-2011.pdf [accessed: 29.02.2012]. 
The 1992 Constitution of the Slovak Republic ${ }^{12}$ follows the ideas and the spirit of these documents - the Universal Declaration of Human Rights from 10 December 1948; the Convention of Fundamental Rights and Freedoms principles and agreements on the integration process in Europe; principles of cooperation by the spirit of the equality of states.

The 1992 Constitution of the Slovak Republic, in its preamble acknowledges the spiritual heritage of Cyril and Methodius and the historical legacy of the Great Moravian Empire. In Chapter One of the Constitution of the Slovak Republic (General Provisions) in Article 1 (1) the basic principle is to be found: "The Slovak Republic is a sovereign, democratic state governed by the rule of law. It is not bound by any ideology or religion". Article 24 of the Constitution guarantees freedom of thought, conscience, religion and faith. This right includes the right to change religion or faith. Everybody has the right to refrain from a religious affiliation. Every person has the right to express freely his or her own religious conviction or faith, either alone or in association with others, privately or publicly, by worship, religious services and ceremonies, or participate in religious instruction ${ }^{13}$.

Article 24 is part of Chapter Two of the Constitution of the Slovak Republic, and it regulates fundamental rights and freedoms. It contains general provisions, fundamental human rights and freedoms, political rights, rights of national minorities and ethnical groups, economical, social and cultural rights, right to environmental protec-

${ }^{12}$ No. 460/1992 Zb. as implemented in Constitutional Act 244/1998 Z.z., Constitutional Act 9/1999 Z.z., Constitutional Act 90/2001 Z.z., Constitutional Act 140/2004 Z.z., Constitutional Act 323/2004 Z.z.

${ }^{13}$ (1) Freedom of thought, conscience, religion and faith shall be guaranteed. This right shall include the right to change religion or faith and the right to refrain from a religious affiliation. Every person shall be entitled to express his or her opinion publicly. (2) Every person shall have the right to express freely his or her own religious conviction or faith alone or in association with others, privately or publicly, by worship, religious services or ceremonies and participation in religious instruction. (3) Churches and ecclesiastical communities shall administer their own affairs. All ecclesiastic authorities and appointments, religious instruction, establishment of religious orders and other religious institutions shall be separate from the State authorities. (4) The rights under sections (1) to (3) of this Article can be legally restricted only as a measure taken in a democratic society for the protection of the public order, health, morality, and rights and freedoms of other people. 
tion and cultural heritage, right to judicial and other protection. The fundamental rights and freedoms create the most extensive part of the Constitution of the Slovak Republic, which follows from the necessity to enshrine the regulation of these rights in the Constitution directly and is one of the most characteristic features of constitutions of democratic countries.

\section{LEGAL FRAMEWORK}

Principal questions of status and activities of churches and religious societies in the Slovak Republic are regulated by Act 308/1991 Zb. on the freedom of belief and the position of churches and religious societies as subsequently amended. The issue of financing of churches and religious societies has been regulated by Act 218/1949 Zb. on the economic support of churches and religious societies by the State as amended by the Act $16 / 1991^{14}$. The Act $308 / 1991 \mathrm{Zb}$. on the freedom of belief and the position of churches and religious societies, as amended by Act 394/2000 Z.z. and the Act 201/2007 $7^{15}$, assumes the provisions of Article 24 of the Constitution and specifies them. It stipulates that confession of religious belief must not be the reason for restriction of constitutionally guaranteed rights and freedoms of citizens, first of all of the right to education, to work and free choice of employment and access to information. It also stipulates that the believer has the right to celebrate festivals and services according to the requirements of his or her own religious belief, in accordance with generally binding legal rules.

The Act 308/1991 Zb. on the freedom of belief and the position of churches and religious societies considers a voluntary association of persons of the same belief, in an organization with own structure, bodies,

${ }^{14}$ M. Moravčíková, M. Cipár, Cisárovi cisárovo. Ekonomické zabezpečenie cirkví a náboženských spoločností, Bratislava 2001, p. 57-81.

15 The Act 201 from 29 March 2007, amending and supplementing the Act 308/1991 Zb. on the freedom of belief and the position of churches and religious societies as amended by the Act 394/2000 Z.z. 
internal regulations and services, to be a church or religious society. Churches and religious societies are legal entities, and can associate freely. They may create communities, religious orders, associations and similar institutions. Churches and religious societies are special types of legal entity taking advantage of a special status (according to Art. 24 of the Constitution) and also other rights awarded to legal entities in general. It is a case particularly of inviolability of privacy, of protection of property, name and inheritance, of inviolability of letters, freedom of movement and residence, freedom of expression and right to information, right to petition, right to assemble and associate, the right to judicial and legal protection etc.

The State recognizes only churches and religious societies that are registered. According to the Act 308/1991 Zb. as subsequently amended, the registration body is the Ministry of Culture of the Slovak Republic. The preparatory body of a church or religious society may apply for registration if it can prove that at least 20000 adult persons - citizens of the SR who are domiciled within the territory of the Slovak Republic - claim membership of the church or religious society ${ }^{16}$. The application for registration must also contain basic documents of the church or religious society to be founded, as well as affirmations of at least 20000 adult members, who are domiciled within the territory of the SR and are citizens of the Slovak Republic, that they claim allegiance to the church or religious society, support the proposal for its registration, are its members, know its basic articles of faith and its doctrine and are conscious of rights and freedoms following from the church or religious community membership ${ }^{17}$.

In the period between coming into force of the Act 308/1991 Zb. on the freedom of belief and the position of churches and religious socie-

${ }^{16}$ Art. 11 of the Act 201/ 2007 Z.z. The majority of registered churches and religious societies evidently do not fulfil the relatively high membership condition. These churches and religious societies were registered under the provision of the Law stipulating that churches and religious societies, already pursuing their activities either under the Law or on the basis of State consent by the date of the Law coming into force, are considered as registered. The majority of churches and religious societies in the Slovak Republic work on the basis of deemed registration.

${ }^{17}$ Art. 11d of the Act 201/2007 Z.z. 
ties, and coming into force of Act 201/2007 Z.z., i.e. until 1 May 2007, only those religious societies were registered that reached the stipulated membership minimum of 20000 . It was expressed by signatures on a petition attached to the basic documents of the church to be founded, which could be signed - according to the then valid legislation, when the details of the registration of churches and religious societies were regulated by the Act 192/1992 Zb. on the registration of churches and religious societies - not only by members of the church to be grounded, but also by supporters of its registration ${ }^{18}$. In this way, registration was achieved by the Religious Society of Jehovah's Witnesses (registered in 1993), the Church of Jesus Christ of the Latter-day Saints (registered in 2006), the Bahá'í Community in the Slovak Republic (registered in 2007). Besides, in 2001 the New Apostolic Church was registered additionally, after it had submitted relevant documents about the State consent to the performance of its activities on the territory of the Slovak Republic before coming into force of the Act 308/1991 Zb.

The above-mentioned framework of state-church relations is also amended by a framework of treaties between the Slovak Republic and the Holy See, and between the Slovak Republic and registered churches and religious societies.

The possibility to conclude agreements with the State was granted to churches and religious societies by the Act 394/2000 Z.z. amending the Act 308/1991 Zb. on the freedom of belief and the position of churches and religious societies. The Catholic Church and eleven other churches made use of this possibility.

An important highlight in the Slovak church policy and the international law was the signing of the Basic Treaty between the Holy See and the Slovak Republic ${ }^{19}$. The National Council granted its consent to the Basic Treaty on 30 November 2000 (Resolution of the National Council

${ }^{18} \mathrm{Cf}$. Reply of the Ministry of Culture of the SR to the request for information on the basis of the Information Act 211/2000 Z.z. (MK - 65/2001 - IZ from June 7, 2001), according to which "laws regulating the registration of churches and religious societies do not stipulate the motivation of persons when signing the signature sheet declaring their affiliation to a church or religious society, therefore it need not mean their membership according to the internal statutes of the given church or religious society".

${ }^{19}$ Published on 23 August 2001, under no. 326/2001 Z.z. (part 136). 
of the Slovak Republic no. 1159). It is a political, international treaty of presidential type. As for the content, it comprehensively regulates the relations between Slovakia and the Holy See. It was signed on 24 November 2000 and came into force upon the exchange of ratification instruments in the Vatican on 18 December 2000.

On 11 April 2002 the President signed the Agreement between the Slovak Republic and the Registered Churches and Religious Societies in the Slovak Republic no. 250/2002 Z.z., which had been granted prior consent by the Government and the National Council. Although of a different nature, the wording of this Agreement is almost identical with the Basic Treaty between the Slovak Republic and the Holy See.

The Basic Concordat between the Slovak Republic and the Holy See has settled, inter alia, that the parties would conclude four other partial treaties.

The first one, the Treaty between the Slovak Republic and the Holy See on Pastoral Care for Catholic Believers in the Armed Forces and Armed Units of the Slovak Republic no. 648/2002 Z.z. came into force on 27 November $2002^{20}$. On the basis of this Treaty, the Ordinariate of Armed Forces and Armed Units was established, having the status of a diocese, and the Ordinary was appointed, having the status of a bishop ${ }^{21}$. The Treaty regulates the pastoral care for Catholics in Armed Forces, Police Corps, in the Unit of Penitentiary Guard and Railway Guards and for persons deprived of freedom by a decision of a State authority. Similar is the Agreement between the Slovak Republic and Registered Churches and Religious Societies on Pastoral Care for Believers in Armed Forces and Armed Units of the Slovak Republic no. 270/2005 Z.z. The Central of Ecumenical Pastoral Care in the Armed Forces and Armed Units of the Slovak Republic was officially opened by a ceremonial service on 10 March 2007. It is the supreme body of the

${ }^{20}$ The President of the Slovak Republic signed the Concordat on 11 October 2002, and the instruments of ratification were exchanged in the Vatican on 28 October 2002.

${ }^{21}$ The Ordinariate has both canonical and state legal subjectivity. The Ordinary is appointed by the Holy See, he is member of the Bishops' Conference of Slovakia and organisationally is included in the Armed Forces of the Slovak Republic. 
second structure of pastoral care in the armed forces and armed units and a parallel structure of the Ordinariate.

Another important source of confessional law is the Treaty between the Slovak Republic and the Holy See on Catholic Upbringing and Education no. 394/2004 Z.z. The similar Agreement between the Slovak Republic and Registered Churches and Religious Societies on Religious Upbringing and Education no. 395/2004 Z.z. was adopted by the Slovak Government by resolution no. 794 on 21 August 2003 and subsequently by the National Council. The wording of this Agreement considers the specifics of the eleven registered churches and religious societies and ensures their statuses equal of those of the Roman Catholic Church and the Greek Catholic Church in establishing church schools and in providing religious education ${ }^{22}$.

The Basic Treaty between the Slovak Republic and the Holy See has anticipated the making of two further, so called partial treaties, and we can presume that also the other registered churches would be interested in making analogous agreements. It's a case of the right to exercise objections in conscience according to the doctrinal and ethical principles of the Catholic Church, and the financial support of the Catholic Church, as anticipated by articles 7 and 20 of the Basic Treaty between the SR and the Holy See ${ }^{23}$.

Act 308/1991 Zb. on the freedom of belief and the position of churches and religious societies, a law at the center of the whole legislative framework of church-state relations in Slovakia, alike other legislation norms mentioned above, arranges only the church-state issue. It does not apply to philosophies of life. Any law or a subordinate legal norm exist that would in any way constitute principles of relationship between the public authorities and philosophies of life. p. 139.

${ }^{22}$ M. Čeplíková, Štát, cirkvi a právo na Slovensku. História a súčasnost', Košice, 2005,

${ }^{23}$ Cf. M. Moravčíková, A. Riobó Serván, Acuerdos entre la República Eslovaca y la Santa Sede, „Revista General de Derecho Canónico y Derecho Eclesiástico del Estado“ 2009, No 21. 
IMPORTANCE OF STATE AND RELIGION INTERACTION AND OTHERS PHILOSOPHIES OF LIFE

According to the Competency Law regulation, the central state authority in the matters of churches and religious societies is the Ministry of Culture of the Slovak Republic. The State neither interferes in church activities, nor regulates them methodically. The Ministry of Culture passes generally binding regulations on the position and activities of churches and religious societies, carries out tasks connected with the preparation of the draft budget for churches and religious societies within the State Budget, coordinates the proceeding of churches and religious societies in settling financial relations with the State Budget, allots financial resources of the State Budget that are intended for churches and religious societies and charity, and oversees their effective and economical use. It also finances geodetic work related to the fulfilment of the law on the reduction of some property damages inflicted on churches and religious societies, carries out church registration and keeps files of legal entities deriving their legal personality from the registered churches.

The Government of the Slovak Republic has a Vice-Chairman for knowledge society, European affairs, human rights and minorities. Its portfolio also includes culture, and churches and religious societies. It is, however, interesting that the President and Prime Minister meet all supreme representatives of churches and religious societies every year (each of them separately usually in the beginning of the year), and not the mentioned Vice-Chairman. This indicates the importance that is attached to the relation between churches and religious societies and the State. Also, the Prime Minister meets every year ad hoc with representatives of individual churches upon his own initiative. Discussions are held behind closed doors and are usually presented as discussions dealing with the cooperation between the State and churches in search for solutions of social issues. In general, church representatives see these meetings as an opportunity for discussing issues related to church education, church property and current partial society-wide matters.

The Catholic Church enters in the dialogue with public authorities specifically - through the Bishop's Conference. The Slovak Bishop's 
Conference has a 4-member Permanent Council which acts operatively, and other specific committees and councils. Committees and councils strive for cooperation, i.e. they promote plans of the Church in various areas of life, from social assistance, health-care, education, science, business environment to art and involvement of Catholics in public life.

The most active players in the dialogue between believers and the State (or public authorities) are formal or informal blocks of especially young activists, which were set up mainly to pursue specific goals. Those are, above all, pro-life organisations and activists of various petition committees which respond to current issues. We can mention, for example, two petition committees which were set up in this way: one committee lobbying for the adoption of the treaty on the possibility to apply objection of conscience, and the other committee that was against this possibility ${ }^{24}$.

Another important player is the Ecumenical Council of Churches in the Slovak Republic which unites seven Christian churches ${ }^{25}$ and has five observers ${ }^{26}$. It establishes, inter alia, a platform for the cooperation with public authorities. For example, the expert committee for the development of a new model of financing churches in Slovakia comprises, apart from relevant state bodies, three representatives of the Catholic Church and three representatives of churches united in the Ecumenical Council of Churches. The committee has also one representative of Jewish religious societies.

Ideas of ecumenical movement often serve as a basis for efficient cooperation between churches and public authorities on the regional and local levels too. The Slovak Republic is divided into eight local administration units - regions, counties, which are divided in districts. Each region is led by an administrator, head of the county and citizens of a region elect representatives on a territorial principle - deputies of a regional parliament. Executive power is represented by regional

${ }^{24}$ Cf. Conscientious objection, ed. M. Moravčíková, Bratislava 2006, p. 377-378.

${ }^{25}$ Lutheran Church of the Augsburg Confession, Orthodox Church, Reformed Christian Church, Brother's Unity of Baptists, Brethren Church, Evangelical Methodist Church, Czechoslovak Hussite Church.

${ }^{26}$ Roman Catholic Church, Greek Catholic Church, Church of the Seventh Day Adventists, Old Catholic Church. 
authorities that have departments whose aim is to efficiently communicate with churches and religious societies. In general, this area is connected with culture or social issues. Regions or districts in which the government recently vested most powers in elementary and higher education as a part of the reform of state and public administration, regularly communicate with churches and promoters of schools and educational institutions. Departments of social issues necessarily cooperate with churches and religious societies as promoters and operators of various social-care facilities. Those are professional sections within public administration.

On the local level, especially in larger cities where several churches are active, there are committees for churches as a part of municipalities. These are advisory bodies to which representatives of all registered churches active in the given region are invited to. Apart from practical matters, they themselves present proposals for improvement of life in the city. Churches are important cultural players in cities. Church facilities are also places of cultural events organised by churches and religious societies.

The 40-year communist period and related forced atheism of society are probably reasons why Slovaks in general do not trust different non-religious ideological associations which are very common especially in Western Europe. In the past, the adjective "ideological" was a synonym of "atheistic". In 1990 a civil association Prometheus was set up. Its founding members are usually top representatives of Marxist-Leninist philosophy before 1989, who worked in the Institute of Scientific Atheism (1971-1990). The Institute of Scientific Atheism (ISA) organised seminars, symposia, conferences for journalists and promoters of atheism - both domestic and foreign. In 1973 to 1989 ISA published "Atheism - a magazine for scientific atheism issues". After 18 years of activity the leader J. Čelko stressed the importance and work of ISA and the magazine "Atheism" (Ateizmus no. 6, 1989, p. 610-11) as follows: "The Institute of Scientific Atheism" became a training centre for people promoting atheistic propaganda especially for universities. Magazine "Ateizmus" performed the role of a collective organiser of professionals in the area of developing Marxist-Leninist atheism across Czechoslovakia. It became known even abroad, 
authors from different socialist countries published their articles in it. The aim of this organisation is, as stated in the Articles, to promote democracy and improve its institutions in the Slovak Republic; defend human rights and fundamental freedoms in general, but also with special regard to freedom of thought, conscience, religious belief and humanist conviction; advocate interests of citizens without religious belief and promote pluralism, tolerance and cooperation between supporters of various thinking movements. They pursue these objectives especially through developing research and documentary activities, educational and other cultural activities, organising seminars, symposia, conferences, publishing activities and other actions based on world humanism and world ethics. They also support civil engagement, promote ideas emphasising family-planning and modern family, carry out social and charity activities vis-à-vis members of Prometheus and other citizens of the Slovak Republic, make efforts focused on the protection of nature and improvement of environment.

Prometheus is a member of the European Humanist Federation, International and Ethical Union and Slovak Humanist Council. It cooperates with other organisations too, e.g. European Commission against Racism and Intolerance of the Council of Europe. Prometheus considers dialogue to be the main method of its work, and cooperation with people of various opinions to be its credo. However, its thinking intention is well documented by the following new-year wish: "We, humanists, enter the new year 2006 with optimism and determination to further advocate the right of thought, act against the interference of religions in matters of the State and the forcing of religious ideas onto all society. We do not fight religions, rather we bring further education, open mind to everyone who wishes to use his/her own brain and not to repeat religious traditions of parents, grandparents, or other ancestors. We are not against religions, God or believers. Why are we then against religions in general? Not only because they lie! But: They declare lies for truth. They halt progress. The parasite, they cheat. They separate people, excuse slavery, shift hopes of a man to life after death. They deprive a man of sense of life. Etcetera, it is never-ending. Dear believers, read scientific, historic, humanistic, liberal and atheistic books about religions and think about it! Friends humanists, agnostics, atheists, do 
not be shy to spread ideas of science, reason and progress, if you are confronted with opinions which you are lived out and they got into the $21^{\text {st }}$ century only by inertia" 27 .

On one hand, Prometheus declares dialogue and cooperation with people of different opinions. On the other hand, through their hostile declarations, published literature and magazine Prometheus they mock and attack religions, churches, their representatives and believers, and representatives of the State too. It seems that the main motto is the one we find on the website of the organisation in the section speaking of 20 years of activity: "Twenty years of work in support for democracy, 20 years of advocacy of rights of citizens without religious belief, 20 years of fight against superstition and prejudice"28. An Anti-religious and anti-church attitude is apparent and dominant, which clearly determines the circle of possible candidates for membership or cooperation, which hinder the possibility of communicating with public authorities.

Apart from the discussed registered churches and religious societies, other, new and nontraditional religious societies are active in Slovakia too. This title ("nontraditional religions") is adequate only from the perspective of Slovak reality, because those religions embrace communities derived from ancient religious traditions such as Buddhism, Hinduism and Islam. In general we can name them unregistered religious societies since they have not gained legal personality on the basis of Act No. 308/1991 Z.z. on freedom of religious faith and the position of churches and religious societies. Many of them have the status of civil associations, they use other ways of acquiring legal personality (foundation, non-investment fund, business company, etc.) or do not have legal personality at all. Mormons, Baha'i Community, Jehovah Witnesses and the New Apostolic Church were recently registered. Unregistered churches wish to be involved in the dialogue with public authorities. They mainly seek to find the possibility to register themselves according to Act No. 308/1991 Z.z. on freedom of religious faith and the position of churches and religious societies. They also participate in religious, social and cultural events. Since conditions

\footnotetext{
${ }^{27}$ Cf. Spoločnost' Prometheus [online]. http://slovakia.humanists.net.

${ }^{28} \mathrm{Cf}$. Prometheun u nás [online]. http://prometheus.unas.cz/
} 
for the registration are rather strict, discussion about the possibility to change the system of registration is being opened quite often. Perhaps extensive criticism or pressure from abroad led the General Prosecutor to file a motion with the Constitutional Court of the Slovak Republic in which he challenged constitutionality of Act No. 308/1991 Z.z. on freedom of religious faith and the position of churches and religious societies. As indicated in the motion, General Prosecutor considers the condition of especially 20000 declarations of honour (condition for the registration of a church) as unconstitutional and discriminatory. On 3 February 2010 the Constitutional Court rejected the motion of General Prosecutor and decided that the condition of holding the declaration of honour of 20000 citizens of Slovakia with domicile in the territory of the Slovak Republic is not unconstitutional. The court arrived at the conclusion that the registration of a church is not a necessary condition for the possibility to freely express one's belief. Despite the decision of the Constitutional Court, it is expected that small, unregistered churches will be making an effort to get legal personality as other churches have. There are several initiatives to introduce a 2-instance registration, as it is e.g. in the Czech Republic. On the local level, it is expected that cooperation between public authorities and churches and religious societies will intensify. Prometheus will be certainly interested in this kind of cooperation too. Furthermore, also in the context of slowly upcoming parliamentary elections, we expect that the requirement for the conclusion of the agreement on the exercise of conscientious objection will be revived.

\section{BIBLIOGRAPHY}

Čeplíková M., Štát, cirkvi a právo na Slovensku. História a súčasnost', Košice 2005.

Clara pacta - boni amici. Zmluvné vzt’ahy medzi štátom a cirkvami, eds. M. Šmid, M. Moravčíková, Bratislava 2009.

Grman Š., Hudek L., Ústava Slovenskej republiky. Stručný komentár, Bratislava 1992.

Matoušek S., Zdobinský S. et al., Štátne právo ČSSR, Bratislava 1987. 
Medzinárodné a vnútroštátne právne aspekty subjektivity osobitných subjektov medzinárodného práva a cirkví a náboženských spoločností, eds. M. Šmid, M. Moravčíková, Trnava 2013.

Moravčíková M., Cipár M., Cisárovo cisárovi. Ekonomické zabezpečenie cirkví a náboženských spoločností, Bratislava 2001.

Moravčíková M., Cipár M., Religiozita na Slovensku II, Bratislava 2003.

Moravčíková M., State and Church in the Slovak Republic, in: State and Church in the European Union. (2 edition), ed. G. Robbers, Baden-Baden 2005.

Moravčíková M., Religious Education and Denominational Schools in the Slovak Republic, in: Islamische Erziehung in Europa / Islamic Education in Europe, ed. E. Aslan, Wien-Köln-Weimar 2009.

Moravčíková M., Riobó Serván A., Cooperación del Estado con las Iglesias en Materia de Educación: La República Eslovaca, „Revista General del Derecho Canónico y Derecho Ecclesiástico del Estádo“ 2005, No 7.

Moravčíková M., Riobó Serván A., Acuerdos entre la República Eslovaca y la Santa Sede, „Revista General de Derecho Canónico y Derecho Eclesiástico del Estado" 2009, No 21.

Mosný P., Laclavíková M., History of state and law on the territory of Slovakia, I. From ancient times till 1848, Plzeň 2009.

Riobó Serván A., El derecho de libertad religiosa en la República Checa y en la República Eslovaca, Madrid 2005.

Výhrada vo svedomí/Conscientious Objection, ed. M. Moravčíková, Bratislava 2007.

\section{RELACJE PAŃSTWO - KOŚCIÓŁ ORAZ ZASADA ŚWIECKOŚCI \\ PAŃSTWA W REPUBLICE SŁOWACKIEJ}

\section{Streszczenie}

Opracowanie traktuje o relacjach Państwo - Kościół oraz zasadzie świeckości państwa w Republice Słowackiej. Ukazuje tło historyczne, sytuację religijno-demograficzną oraz regulacje prawne definiujące stosunek Państwa do religii i gwarancje w zakresie wolności religijnej. Omówione zostały konstytucyjne zasady relacji Państwo - Kościół, zasady finansowania związków wyznaniowych, procedura rejestracji kościołów i innych związków wyznaniowych, działalność organizacji religijnych w przestrzeni publicz- 
nej, umowy zawierane między Państwem a kościołami i innymi związkami wyznaniowymi, a także wpływ jaki na sferę państwową wywiera religia i inne przekonania światopoglądowe.

Ttumaczenie: Aneta M. Abramowicz

Słowa kluczowe: Republika Słowacji, relacje Państwo - Kościół, konstytucja, religia w przestrzeni publicznej, Stolica Apostolska, umowy miedzy Państwem a związkami wyznaniowymi , finansowanie kościołów, rejestracja kościołów i związków wyznaniowych, przekonania światopoglądowe

Key words: Slovak Republic, State-Church relations, constitution, religion in public space, Holy See, contractual relations, financing of churches, registration of churches and religious societies, philosophies of life 